\title{
The Practice of Food Labels on MSMEs: The Case Study in Bangka Belitung
}

\author{
Levyda Levyda ${ }^{1}$, Kania Ratnasari ${ }^{2}$, Giyatmi Giyatmi ${ }^{3}$ \\ ${ }^{12}$ Management Department Sahid University Jakarta, ${ }^{3}$ Food Technology Department Sahid \\ University \\ \{levyda_mm@yahoo.co.id\}
}

\begin{abstract}
Food labels are very important for consumers, but there are still many food manufacturers that do not provide complete information. Research on food souvenir labels is needed to support tourism. This study aims to analyze the food souvenir labels. The study was conducted on 150 food souvenirs from 20 categories. The sample was selected accidentally in a gift shop in Bangka Belitung. This study uses a comparison method between the availability of information on labels and food label regulations for home industries. There are still many products that do not provide halal information, production dates and nutrition. This information is very important for tourists, therefore the government needs to increase awareness and compliance of micro, small and medium scale food producers.
\end{abstract}

Keywords: Food; Food labels; MSMEs; Bangka Belitung

\section{Introduction}

Food product labels are very important to consumers and producers-the higher consumer awareness on food safety, the more important the role of labels. The food label is a set of written, printed, graphic information that aims to provide an overview of the product and promote [1]. Labels influence consumer purchasing behavior [2], customer trust [3] and enhanced trust [4]. The label serves as a means of communication between producers to consumers, producers to the government, and producers to industry [4]. Labels allow consumers to trust the manufacturer and perceived risk [4]. Labels affect willingness to pay on premium product labels, and labels that emphasize support for animal welfare and agricultural sustainability are preferred [5] and affect purchasing decisions [6] [1].

Food are often used for promotion of tourism destinations. Food has a positive effect on destinations [7]. Food labels will help tourists get to know the processed food they buy at tourist destinations. Labels are very important for tourists so that they are familiar with the food souvenirs they buy [8]. The importance of information on labels includes price and health risk warnings, production date, expiration date, nutrition and content, storage, and use [9]. Purchasing decisions for food products in Indonesia are influenced by price, packaging, nutrition and producers [10]. The label information indicates the quality of the wine [11]. Important information on cow's milk cheese is PDO (Protected Denomination Origin), organic logo, and nutrition [12]. In Indonesia, the halal label influences consumer purchasing decisions [13] [14]. The front of the label that consumers often read is the halal logo, net weight, product name, trademark, registration number, while the back label is often read nutrition information, product composition, expiration date, health claim, product description, 
factory, and others [15]. There are differences in the order of importance of information on labels due to age differences [16]. The habit of reading labels depends on gender, age and education, as well as the influence of labels on purchasing decisions [16].

Based on the Consumer Protection Law Number 8 of 1999 [17], several consumer rights related to labels are "the right to comfort, security and safety in consuming goods and / or services; the right to choose goods and / or services and to obtain goods and / or services, this is in accordance with the exchange rate and the conditions and guarantees promised; the right to correct, clear and honest information regarding the condition and guarantee of goods and / or services; and the right to receive guidance and education for consumers ". The producer is obliged to "provide true, clear and honest information regarding the condition and guarantee of goods and / or services and provide an explanation of the use, repair and maintenance."

The household-scale food industry is required to have a household food industry certificate. Companies are required to provide information on "name of a type of food, trade name, type of packaging, net weight/net content, raw materials and other materials used, production stages, name, address, zip code and telephone number, owner name, name of the insure, information on shelf life (expiration), information on production codes". From the perspective of consumers, labels are very important, as well as from government regulations. Therefore, companies are obliged to provide important information to consumers. This study aims to describe the information listed on the food souvenir label sold in a tourist destination

\section{Methodology}

The survey was conducted on food souvenirs made by MSMEs and sold in food souvenir shops frequented by tourists in Tanjung Pandan and Pangkal Pinang in Bangka Belitung Province. The sample of this research was 150 food souvenirs representing 20 categories of food souvenirs. These samples were selected by accidental sampling method. This study uses a comparison method between labeling practices implemented by MSMEs and government regulations on food labeling in household food businesses.

\section{Result and Discussion}

The information on the label is very important for tourists who buy food souvenirs at the destinations visited. The name of a food souvenir is very important, especially for products that are not well known by tourists. The product name is available on most of products. The America Marketing Association define brand as "A brand is a customer experience represented by a collection of images and idea; often it refers to a symbol such as a name, logo, slogan, and design scheme" [18]. A brand is very important to reach the consumer market and business market. Processed food producers' awareness of brands' role is high - the number of products that already have a brand reaching $90.7 \%$. Brands must be registered as trademarks. Trademark is a combination of various symbols that distinguishes a company's product from other companies [19]. Trademarks are registered to protect brands, leverage brand equity, protect investments from building quality and reputation, protecting intellectual property rights $[20]$. 
Brands play a role in making it easier for consumers to remember the products they purchased and differentiate them from others. MSMEs (Micro Small Medium Enterprises) that produces souvenirs in Bangka Belitung, is very aware of brands' importance; this can be seen from products with very large brands. The manufacturer's address is very important for future business. The manufacturer's address makes it easy for parties who will do business with the producers. From the survey results, only $51.3 \%$ of products listed the address of the manufacturer. The location of the producer is very important.

Table 1. Availability of Information on Food Souvenir Labels

\begin{tabular}{lcc}
\hline \multicolumn{1}{c}{ Label Characteristics } & Available & Not Available \\
\hline Product name & $98.7 \%$ & $1.3 \%$ \\
Name of Manufacturer & $51.3 \%$ & $48.7 \%$ \\
Address of the Manufacturer & $28.7 \%$ & $71.3 \%$ \\
Location of the Manufacturer & $70.0 \%$ & $30.0 \%$ \\
Brand name & $90.7 \%$ & $9.3 \%$ \\
P-IRT (Home Industry & $93.3 \%$ & $6.7 \%$ \\
Products) & & \\
Ingredient description / & $87.3 \%$ & $12.7 \%$ \\
Material composition & & \\
Content description & $98.0 \%$ & $2.0 \%$ \\
Halal label & $34.7 \%$ & $65.3 \%$ \\
Nutritional information & $2.7 \%$ & $97.3 \%$ \\
Production date & $12.7 \%$ & $87.3 \%$ \\
Expired date & $83.3 \%$ & $16.7 \%$ \\
Production code / Bar Code & $58.0 \%$ & $42.0 \%$ \\
Customer service contacts & $14,7 \%$ & $85,3 \%$ \\
\hline
\end{tabular}

Household-scale businesses make many of the processed food sold in souvenir shops. Home-scale food businesses must have a Home Industry Food Production permit [21]. To obtain this certificate, food entrepreneurs must fill out an application form, submit a business permit document and design of food labels, and a food extension certificate. $93.3 \%$ of food products are produced by entrepreneurs who have a Home Industry Food Production certificate; there are still $6.7 \%$ of products produced by companies that do not have a Home Industry Food Production certificate. Processed food producers are required to state the weight of the contents and materials used [21]. The awareness of the MSMEs in the food industry to combine this information is already high. $87.3 \%$ of products already provide information on the raw materials used for food. $98 \%$ of products include weight information. Household scale processed food producers must include nutritional value information on the label. Although important, from the survey results, only $2.7 \%$ of processed foods contained nutritional information.

The halal label is an important clue for Muslim. The employer who has obtained a halal certificate is required to include halal labels on products that have received a halal certificate [22]. From the survey results, only $34.7 \%$ of the products have halal certificates. The supply information system using a barcode scanner helps manage inventory data using a barcode scanner camera [23]. Some MSMEs in the food industry have used barcode scanner information systems to help with inventory management. From the survey, $58 \%$ of products have used a barcode, and $42 \%$ do not have a barcode. MSMEs in the food industry are required to provide expiration date information [24]. Products that provide expiration date information reach $83.3 \%$. The remaining $16.7 \%$ do not provide expiration date information. Only $12.7 \%$ of the products provided production date information. 
The company provides customer service call centers to build long-term relationships with customers. Call centers provide a means for consumers to express customer emotions because customer emotions affect customer satisfaction. Few MSMEs in the food industry care about this. Only $14.7 \%$ of products provide information about customer service. The guidance and supervision of MSMEs needs to be done intensively because there are still many MSMEs that have not provided mandatory information to consumers. The guidance and supervision of MSMEs needs to be done intensively because there are still many MSMEs that have not provided mandatory information to consumers. Quality food souvenirs produced by MSMEs can become tourist attractions and increase the amount of tourist expenditure.

\section{Conclusion}

MSMEs in the food industry is needed to support culinary tourism in Bangka Belitung. The role of labels on food products is very important because tourists cannot be familiar with the food souvenirs to be purchased. Some information on Bangka Belitung food products is still necessary, such as the factory's name and address, nutritional information, halal labels, production dates, and expiration dates. Several companies have realized the need for inventory management by providing barcodes on their products. To build relationships with customers, some companies also provide customer service information. This study only examines the label from the entrepreneur's perspective and uses the label observation method. In the future, it is necessary to conduct a study using the in-depth interview method to explore the views of MSMEs entrepreneurs on the label.

\section{Acknowledge}

This research was funded by the Ministry of Research and Technology of the Republic of Indonesia (National Research and Innovation Agency) and The Tourism Industry Association of Bangka Belitung.

\section{References}

[1] Z. Ariff, A. Latiff, N. Aisyah, and M. Amizi, "Factors Influencing Consumer Purchasing Intention based on Food Labels," Int. Bus. Manag., vol. 13, no. 1, pp. 41-45, 2016, doi: 10.3968/8679.

[2] J. Zekiri and V. V. Hasani, "The Role And Impact of The Packaging Effect On Consumer Buying Behavior," Ecoforum, vol. 4, Special, no. 1, pp. 232-240, 2015.

[3] E. Tonkin, A. . Wilson, J. Coveney, T. Webb, and S. Meyer, "Trust in and through labelling - a systematic review and critique," Br. Food J., vol. 117, no. 1, pp. 318-338, 2015, doi: https://doi.org/10.1108/BFJ-07-2014-0244.

[4] E. Tonkin, T. Webb, J. Coveney, S. B. Meyer, and A. M. Wilson, "Consumer trust in the Australian food system - The everyday erosive impact of food labelling," Appetite, vol. 103, pp. 118-127, 2016, doi: 10.1016/j.appet.2016.04.004.

[5] M. Costanigro, O. Deselnicu, and D. T. McFadden, "Product differentiation via corporate social responsibility: consumer priorities and the mediating role of food labels," Agric. Human Values, vol. 33, no. 3, pp. 597-609, 2016, doi: 10.1007/s10460-015-9640-9.

[6] L. K. Yew, C. Fengqiao, W. C. Hoo, R. Omar, and T. O. Kowang, "The Influence of Packaging Attributes on Customer Buying Decision,” vol. 2020, no. August, 2020. 
[7] N. A. M. Zain, M. S. M. Zahari, and M. H. Hanafiah, "Food and tourism destination image: Moderating effect of local food consumption," e-Review Tour. Res., vol. 15, no. 1, pp. 21-36, 2018.

[8] M. de L. Medeiros, G. S. Horodyski, and J. L. Passador, "Food souvenirs in the perception of the tourist: the case of the artisanal minas Serro cheese TT - Gastronomic souvenirs from the tourists perspectives: the case of the artisanal minas serro cheese TT - Souvenirs gastronômicos na percepção do turista: o,” Rev. Bras. Pesqui. em Tur., vol. 11, no. 2, pp. 347-364, 2017, doi: 10.7784/rbtur.v11i2.1307.

[9] N. Kumar and S. Kapoor, "Do labels influence purchase decisions of food products? Study of young consumers of an emerging market," Br. Food J., vol. 119, no. 2, pp. 218-229, 2017, doi: 10.1108/BFJ-06-2016-0249.

[10] D. D. Y. Tarina, S. M. D. Hutabarat, and M. Sakti, "Implementation of Labeling Standars For Food Packaging Products In Indonesia,” Int. Journals Multicult. Multireligious Underst., vol. 6, no. 1, pp. 1-20, 2019.

[11] E. Dimara and D. Skuras, "Consumer demand for informative labeling of quality food and drink products: A European union case study," J. Consum. Mark., vol. 22, no. 2, pp. 90-100, 2005, doi: $10.1108 / 07363760510589253$

[12] T. de-Magistris, A. Gracia, and J. Barreiro-Hurle, "Do consumers care about European food labels? An empirical evaluation using best-worst method," Br. Food J., vol. 119, no. 12, pp. 2698-2711, 2017, doi: 10.1108/BFJ-11-2016-0562.

[13] I. Alfian, "Analisis Pengaruh Label Halal, Brand dan Harga Terhadap Keputusan Pembelian di Kota Medan," At-Tawassuth, vol. Vol.2, No., p. 127, 2017.

[14] B. Rizki Arlisa, R. Hendayani, and Y. Ganesan, "Foreign Halal Packaged Products that Influence Purchase Intention," Asian J. Technol. Manag., vol. 12, no. 2, pp. 86-93, 2019, doi: 10.12695/ajtm.2019.12.2.1

[15] U. Sumarwan, M. Simanjuntak, and L. N. Yuliati, "Meta-Analysis Study: Reading Behavior Of Food Products Label,” J. Consum. Sci., vol. 2, no. 2, p. 26, 2017, doi: 10.29244/jcs.2.2.26-40.

[16] H. N. Fadlillah, L. Nuraida, and E. H. Purnomo, "Consumer Awareness on Label of Food Packaging and Information of Food Additives in Bogor City Kepedulian Konsumen terhadap Label dan Informasi Bahan Tambahan Pangan ( BTP ) pada Label Kemasan Pangan di Kota Bogor,” J. Mutu Pangan, vol. 2, no. 2, pp. 119-126, 2015, doi: 10.13140/RG.2.2.11432.32000.

[17] Undang - Undang Republik Indonesia Nomor 8 Tahun 1999 Tentang Perlindungan Konsumen. 1999 , p. 80.

[18] F. D. Riley, "Brand definitions and conceptualizations: the debate," in The Routledge companion to contemporary brand management, no. January, 2016, pp. 35-44.

[19] WTO, "Module III Trademark."

[20] M. Flikkema, C. Castaldi, A. P. de Man, and M. Seip, "Trademarks' relatedness to product and service innovation: A branding strategy approach," Res. Policy, vol. 48, no. 6, pp. 1340-1353, 2019, doi: 10.1016/j.respol.2019.01.018.

[21] B. Pengawas et al., Badan Pengawas Obat dan Makanan Republik Indonesia, no. 88. 2018, pp. 1155.

[22] Undang-Undang Republik Indonesia Nomor 33 Tahun 2014, vol. 53. Indonesia, 2014, pp. 1-40.

[23] I. P. A. Putra Yudha, M. Sudarma, and P. Arya Mertasana, "Perancangan Aplikasi Sistem Inventory Barang Menggunakan Barcode Scanner Berbasis Android," J. SPEKTRUM, vol. 4, no. 2, p. 72, 2018, doi: 10.24843/spektrum.2017.v04.i02.p10.

[24] BPOM, Lampiran Peraturan Badan Pengawas Obat dan Makanan, Nomor. HK.03.1.23.04.12.2205, no. HK. 03.1.23.04.112.2205. Indonesia: Lampiran Peraturan Kepala Badan Pengawas Obat Dan Makanan Republik Indonesia, 2012, pp. 1-34. 